Војин Недељковић

Универзитет у Београду

Филозофски факултет
UDC $371.3:: 811.124^{\prime} 02+811.14^{\prime} 02$

DOI https://doi.org/10.18485/fid.2018.8.ch7

\title{
О КЛАСИЧНОЈ И ПОСЕБНО ЛАТИНСКОЈ НАСТАВИ У МОДЕРНОЈ СРЕДЊОЈ ШКОЛИ
}

\begin{abstract}
Сажетак
Аутор најпре говори о томе како је сврха класичне наставе у нововековној европској школи бивала различито дефинисана, а затим тврди да унутар модерног средњошколског курикулума класичној настави треба доделити улогу интегратора хуманистичког образовања. Напослетку разматра шта та улога подразумева и који би били предуслови њеног испуњења.
\end{abstract}

Кључне речи: класична традиција, хоризонтално повезивање школске материје, улога граматике у језичкој настави, услови рада у данашњој српској школи.

Најпре једна терминолошка напомена. Овде где ми говоримо

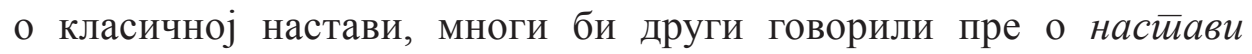
класичних језика. Ја имам два разлога што чиним овако. Термин класична насйава стар је и освештан компетентном употребом, ${ }^{1}$ и не видим по чему би се он морао преправљати - ако не по извесној синтактичкој моди која би данас хтела да све мушке фризере унапреди у »фризере за мушкарце«. А друго, класична настава у легитимном извођењу није никад била чисто језичка; ${ }^{2}$ могло би се, штавише, доказивати да у њеној композитној природи лежи битан

1 Доста је имати у виду темељну беседу Јована Туромана одржану »на св. Саву год. 1884 у Великој школи« (Туроман 1884). — О Туроману, заснивачу класичних студија на Великој школи, чији погледи ни данас нису без интереса, в. Недељковић 2004.

2 Обиље сведочанстава о прожимању класичне наставе с другим хуманистичким предметима у српској школи XIX и XX века доноси Бошков 2016. 
део њене вредности. Зато је боље и не називати је тако да јој се домен већ у називу ограничи на језик или језике.

Два класична језика, грчки и латински, неједнако су заступљена у нашој данашњој школи. Класични грчки се у Србији предаје ђацима класичних одељења двеју филолошких гимназија, а на универзитету га уче, сем будућих класичних филолога, богослови, неохеленисти, а по избору и студенти других филолошких и »историјских« група. Латински се у филолошким гимназијама и одељењима предаје четири године, а у другим средњим школама, зависно од профила, две године, годину дана, или уопште не; у неким стручним школама течај латинског прилагођен је струци. На универзитету, латински је, осим на самој класичној филологији, заступљен на модерним филологијама и »историјским« студијским групама што обавезно, што по избору, а латинске наставе има и по школама медицинске и правне групације. Имајући све то у виду, ми се овде концентришемо на средњу школу као место где се већина сусреће с класичном наставом, и у том оквиру на латински као превасходни предмет те наставе.

Класична настава - латинска, пре свега - задуго је била главна садржина европског образовања, па се и данас она може сматрати једним од његових заштитних знакова, исто као што, у једном ширем контексту, европску цивилизацију као такву обележава класична традиција. По томе судећи, сврха класичног образовања, па и латинске наставе, имала би да буде ван сваке сумње. Утолико је интересантније видети како се током последњих неколико столећа европске школе та сврха различито одређивала: ${ }^{3}$ од практичне нужде да се научи језик надрегионалне и међунационалне, као и стручне и професионалне комуникације, преко начелне потребе да се образованом човеку омогући приступ несагледивом мноштву текстуалних сведочанстава заосталих иза цигло две хиљаде година европске прошлости, ${ }^{4}$ све до замисли да знање латинског представља неопходну допуну знању матерњег и основу за усвајање модерних страних језика.

Но, класична настава се давно и оспорава. Понекад се то односи на саму класичну цивилизацију, тј. на васпитно-образовну вредност

3 Види Waquet 1998.

4 О саставу и размерама тог корпуса згодно Leonhardt 2009, 1-8. 
њеног изучавања у школи и, нарочито, њеног уздизања на разину недостижног и незамењивог. ${ }^{5}$ Чешће, оспоравање се односи на корист од иоле ширег изучавања латинског језика, или, специфично, на методе којима се он учи у школи. Неминовно, те методе стоје у дугој традицији латинске глотодидактике, која, никад непрекинута, сеже чак у античко доба ${ }^{6}$ - и већ сама ова чињеница довољна је да побуди супротне реакције једних који сшиаро виде као проверено и афирмисано и других који га виде као овештало и зрело за отпис.

Било како било, општеобразовни значај латинске наставе у стању је полаганог али укупно знатног опадања. Данас већ ваља признати да образован човек, па и научник, чак и у самој области хуманиора, може бити, и бива, и без латинског. Међутим, сенка великог имена још је ту: и данас, интелектуалци различитих профила изричито држе до тога што су у школи учили латински и поносе се тим својим знањем. Ово се наравно може узети као повољна околност - једна, међу многим другим неповољним. Јер, ради опстанка и успеха латинске наставе данас је неизбежно сукобити се с неким утицајним стереотипима. Први од њих, који на известан начин погађа сву језичку наставу, то је систематска и све већа предност дата визуалној комуникацији науштрб вербалне у појединостима које чине свакодневну рутину великог броја људи. Други, који погађа сваку историјску поуку, то је замисао да се не треба »оптерећивати« прошлошћу, јер није важно шта је било, треба се окренути будућности. Најзад, трећи стереотип, који се тиче школе у целини, то је захтев да се учи највише »оно што ће стварно требати у животу« - иако је јасно да се у свету овако брзих и

5 Ово нек нам илуструје један старији домаћи пример, светосавска (опет!) беседа крагујевачког професора Јована Несторовића, у којој се каже и ово: »[3] ap би јаче образовање у духу класичном било за нас претежније од темељнијег проучавања пољске економије...? Зар би нам Сократова причања о бесмртности душе више користила од знања, каква је земља згоднија за који

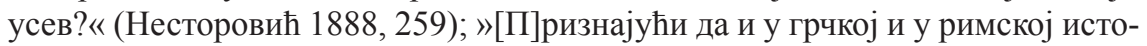
рији има дивних идеала, морамо додати, да их има и у српској... Зар је на пр. Леонида већи јунак и родољуб од нашега Танаска Рајића? ... Па зар Милош Обилић није наш Муције Сцевола...? (ibid., 293).

6 Расположива сведочанства античке и раносредњовековне латинске глотодидактике фасцинантно су презентирана код Dickey 2016. 
дубоких промена практична знања тешко дају формулисати годинама унапред, па је још утолико важније посветити школу и школовање стицању фундаменталних знања и развоју општих способности.

Сви ми филолози данас схватамо да настава језика̂ у основној и, поготову, средњој школи не сме бити уређена само као списак појединачних течајева у пракси подложних лаичкој симплификацији, која матерњи језик у школи своди на »правопис« (схваћен растегљиво, некад и наопако), а страни језик, махом енглески, прихвата и хоће само »да би га причали«. Напротив, потребно је имати у виду једну општију сврху и спровести један виши ступањ организације; друкчије речено, у склопу школскога курикулума језички блок треба да чини целину осмишљену и организовану боље него досад.

У њеној основи природно лежи настава матерњег језика. О самој тој настави, разуме се, ја не могу да судим. Са становишта наставника који се по потреби свог посла ослања на матерњу компетенцију ђака, налазим да је знање матерњег језика код многих слабо, не само у дескриптивном или прескриптивном смислу (до овога, на крају крајева, не мора увек бити стало), већ пре свега по томе што многи не владају, пасивно као ни активно, изражајним моћима српског, чинећи безмало утисак тзв. полукомпетентних матерњих говорника каквог угроженог језика. Може бити да би оно пажње што се, не само у школи већ и јавности, посвећује матерњем језику требало преусмерити с конвенционалних појединости наше језичке норме ка виталним питањима прецизности и експресивности, као и лексикалне и фразеолошке аутономије српског језика.

Што се тиче латинске наставе данас, прво на чему треба легитимно да инсистирамо јесте ендоцентричност њене примарне сврхе. Латински вреди учити пре свега да би се овладало самим тим језиком, на којем се има шта прочитати са огромном, несагледивом коришћу: ${ }^{7}$ ако је истина да хуманистичког образовања данас може

7 Ову поенту изводи Miraglia 2009, нарочито 5: $\gg$ il latino porta tanti [benefici collaterali] ... a chi lo sa, ... ma è nel latino stesso [курзива је изворна], nell'incalcolabile peso culturale che esso ha come chiave d'infiniti tesori del nostro patrimonio ... che sono da ricercarsi le ragioni non solo della sua sopravvivenza, ma ... della sua promozione, della sua crescita, della sua valorizzazione a livello scolastico è universitario.« 
бити и без латинског у школи, истина је и да је оно с њиме неупоредиво боље засновано и кудикамо потпуније. Уз то, латинска настава треба да очува и унапреди своју секундарну сврху, давно признату и по много чему не мање важну од примарне. Позната је ствар да латински језик, типолошки гледано, стоји између српскога, с којим има много додирних тачака у области морфологије, синтаксе и прагматике, и већине страних језика који се уче у нашим школама, како романских, који су од латинског потекли, под његовим утицајем се развили и њиме се вишеструко расветљавају, тако и енглеског, чији се лексички фонд, са историјских разлога који такође заслужују пажњу, заснива већином на латинскоме. По томе, латинска настава може и треба да унутар језичког блока има улогу интегратора. Ово значи да школска дескрипција латинског језика и руковање латинским језичким материјалом има да служи, осим унутарњој потреби латинске наставе, још и ревизији и координисању различитих знања о српском и модерним страним језицима: о њиховој структури, њиховој историји, њиховој интеракцији. Уређен с поуздањем у вредност упоредноисторијског приступа језику и језицима, блок базиран на настави матерњег и интегрисан наставом латинског језика може да постане узорна инстанца хоризонталног повезивања школске материје.

Ради овога, саму латинску наставу треба ${ }^{8}$ довести, пре свега у појмовно-терминолошком смислу, у ближу везу и склад с наставом матерњег и модерних страних језика. Тврдња да то до данас још није довољно постигнуто дала би се поткрепити одвећ великим бројем примера; овде нек буде довољан један минијатуран узорак, као назнака проблема. У области синтаксе, рецимо, било би разумно кад би се латинска номинална синтагма описивала истим средствима и по

8 За један концепт латинске наставе у нас, в. Маневић-Шијачки 1998; за неколико новијих запажања, Недељковић 2016, 5-14. Релативно су модерно засновани и адекватно израђени нови програми класичне наставе објављени у Просвейном йласнику 1/2017 као део Правилника о наставном плану и програму за обдарене ученике у Филолошкој гимназији. - Користан страни приручник је Giordano Rampioni 2010, а с једног нарочитог становишта и Miraglia 2009. Главни периодик у овој области одавно је $A U$; модерни и амбициозни часопис Docere излазио је 2002-3 па престао, а цела серија данас стоји расположива на vivariumnovum.it/risorse-didattiche/propria-formazione/docere. 
истим линијама као српска, која јој је умногоме слична; и, недалеко од овога, кад би се ради описа латинских »предикативних« конструкција узеле у обзир извесне корисне дистинкције (нпр. атрибутив, актуални квалификатив) које познаје и спроводи српска школска граматика. ${ }^{9}$ Или ово: вредело би ђацима представљати латински конјунктив најпре у оним улогама које су у исти мах најфреквентије у самом латинском и најсличније ономе што се има по романским језицима и граматикама; код нас се, међутим, одувек поступа супротно: полази се од независног конјунктива, на име тога што се он, упркос својој значајно мањој учесталости у латинском тексту, може сматрати фундаменталним у историјском, а донекле и системском погледу.

Логично је упитати: због чега латинска настава у српској школи није већ данас заснована овако како бисмо желели и осавремењена колико је потребно? То се питање поставља још утолико оштрије уколико узмемо у обзир разлику, чудну наизглед, између онога што се практикује у матичној академској установи, на Одељењу за класичне науке Филозофског факултета у Београду, и наставе по школама. Наша класична филологија релативно је отворена за разне концепте и пријемчива за утицаје: зашто, онда, из те школе излазе стручњаци који, кад почну предавати латински, ${ }^{10}$ мало чине на осавремењивању наставе?

Један узрок овоме свакако је општи. У давно занемареној националној установи каква је наша просвета, где се на многим нивоима размишља више о опстанку него о напретку, није једноставно изискивати ни од наставника латинског несебичан напор ка усавршавању. Други је узрок тај што је латинску наставу могућно у битноме унапредити тек у контексту ревизије читавог језичког блока. Трећи пак узрок лежи у домену струке: домаћи приручници који стоје на располагању

9 Првенствено имам у виду граматику Станојчић, Поповић 2011.

10 Остављам по страни то што данас у многим школама, с разлога који нису увек легитимни, латинску наставу држе не класични филолози већ наставници из неколико других струка чији високошколски курикулум приде садржи и латински језик. Међутим, на универзитету самом, латинска настава коју слушају будући класични филолози сасвим је несамерљива с течајима латинског језика који се држе студентима других струка. »Мапирана« на потоњи наставнички ангажман у средњим школама, ова разлика се често своди на контраст између компетенције и некомпетенције. 
наставнику латинског - пре свега школске граматике и речници ${ }^{11}$ - данас су по много чему застарели. Тешкоће с којима је скопчана њихова употреба не вреди овде да разматрамо; доста је рећи да они не дају мотива нити праве подршке стручном читаоцу који би хтео да ради унапређења латинске наставе опроба поглед на материју из разних углова. Биће, дакле, неопходно написати нове, боље приручнике - почев, по свему судећи, од речника - и дати их наставницима у руке. ${ }^{12}$

Споменимо на крају и шта сматрамо да би убудуће ваљало избећи. Споља гледано, свест о первазивном присуству латинске језичке грађе у модерним језицима не би смела водити томе да се са̂м латински презентира ђацима у разграђеном стању, као какав каталог лексичких интернационализама и/или инвентар граматичких категорија и термина. Исто тако, интегративна улога латинске наставе не би требало да у битноме значи поправљање другде начињених пропуста: оно што се у нашој средини неретко чује као школска успомена - како су некоме добро дошли часови латинског јер је тек на њима појмио шта су, на пример, падежи - такве ствари су мање комплимент латинској настави, а више показатељ извесних дефеката система, које би, разуме се, требало превазићи. Изнутра пак, морали бисмо пазити да се латинска настава не претвара у течај латинске граматике »насуво« - као што то данас често, чак претежно, бива. Ноторни аргумент из XIX века, да је изучавање класичних језика »најдивнија умна гимнастика, најбоља школа за логично мишљење и расуђивање «, ${ }^{13}$ данас тешко да се може бранити без озбиљних ограда. Ако ништа друго, јасно је да ни у случају

11 Две латинске граматике у широкој школској употреби су Gortan, Gorski, Pauš 1954 и Шијачки-Маневић 1996; од њих је у високом степену зависно и излагање граматике у нашим уџбеницима латинског језика. Као успели страни примери латинске школске граматике израђене по начелима савремене језичке дескрипције могу се узети Lavency 1997 и Panhuis 2005. — Од наших школских речника вредни су спомена Ђорђевић 1886 и Divković 1900; остале који се прештампавају и продају боље је прећутати. Као примеран страни речник латинског за школе може се узети аустријски класик Stowasser/Lošek 2016.

12 О потреби за добро конципираним семинарима за наставнике не треба ни говорити. Блиска идејама које овде излажем била је концепција семинара »Curriculum integratum: латински језик у корелацији с другим предметима средњошколског курикулумащ, у чијем сам извођењу учествовао 2014/15.

13 Туроман $1884,5$. 
латинског, као ни другде, учење језика и учење граматике не могу да важе за једно те исто; ово поготову с обзиром на ванјезички аспект латинске наставе и њену мисију заточнице класичног наслеђа, које у својој разгранатости и преобиљу представља тисућу битних ствари пре него »умну гимнастику« за младо поколење. После часа латинског, питање треба да гласи: шта смо данас прочитали и схватили, а не: шта смо данас деклинирали; зато латинска настава већ по својој унутарњој потреби тражи граматику постављену утилитарно, са штивом у виду.

И најзад: латински не би више требало представљати само у контексту римске цивилизације. Усредсређеност на класичну антику имала је смисла док су се у римској књижевности тражили узори латинског стила: тад је требало угледати се на напредне матерње говорнике, што је значило - на Цицерона и његове савременике школоване за лепу реч. Данас, напротив, ми имамо све разлоге да поимамо и представљамо латински не само као језик старих Римљана, већ такође, ако не и првенствено, као велики језик европске писмености йосле Римљана. И више од тога: кад треба показати онима који ступају у живот да поред свега људског што пролази и умире има нечега што опстаје и тријумфује далеко изван свог минулог доба, за то нема упечатљивијег примера од латинског језика и његове судбине.

\section{Референце:}

$A U=$ Der altsprachliche Unterricht

[www.friedrich-verlag.de/sekundarstufe/fremdsprachen/lateingriechisch/ der-altsprachliche-unterricht].

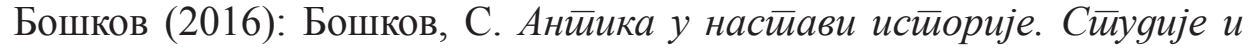
исиираживања, Нови Сад: Филозофски факултет.

Dickey (2016): Dickey, E. Learning Latin the Ancient Way. Latin Textbooks from the Ancient World, Cambridge UP.

Divković (1900 [и репринти]): Divković, M. Latinsko-hrvatski rječnik za škole, Zagreb. ${ }^{2}$

Ђорђевић (1886 [и репринти]): Ђорђевић, Ј. Лайинско-срӣски речник, Београд. 
Giordano Rampioni (2010): Giordano Rampioni, A.. Manuale per l'insegnamento del latino, Bologna: Pàtron. ${ }^{4}$

Gortan, Gorski, Pauš (1954 [и репринти]): Gortan, V., Gorski, O., Pauš, P. Latinska gramatika, Zagreb: Školska knjiga.

Lavency (1997): Lavency, M.. Vsus: Grammaire latine. Description du latin classique en vue de la lecture des auteurs, Louvain-la-Neuve: Peeters.

Leonhardt (2009): Leonhardt, J. Latein. Geschichte einer Weltsprache, München: Beck.

Маневић-Шијачки (1998): Маневић-Шијачки, Б. Мешооика насӣаве лайинской језика, Београд: ЗУНС.

Miraglia (2009): Miraglia, L. Nova via: Latine doceo, Montella: Vivarium Novum.

Недељковић (2004): Недељковић, В., »Јован Туроман«, У: А. Лома (прир.), Saecula confluentia, Београд: Филозофски факултет, 91-99.

Недељковић (2016): Недељковић, В. Studium. Лайински на универзи-

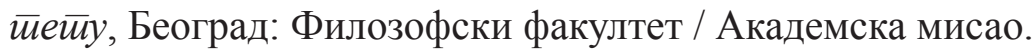

Несторовић (1888): Несторовић, Ј., »Реализам и класицизам«, Просвейни илласник 9, 254-259 и 290-296.

Panhuis (2005): Panhuis, D.. Latin Grammar, Ann Arbor: Michigan UP.

Станојчић, Поповић (2011): Станојчић, Ж., Поповић, Љ.. Грамайика срӣскоі језика за іимназије и среgње школе, Београд: ЗУНС. ${ }^{13}$

Stowasser, Lošek (2016): Lošek F. (прир.), Stowasser: lateinisch-deutsches Schulwörterbuch. Völlige Neubearbeitung. München: Oldenburg.

Маневић-Шијачки (1996): Шијачки-Маневић, Б. Грамайика лайинскої језика, Београд: ЗУНС.

Туроман (1884): Туроман, J., »Класична настава у нашим гимназијама«, Гласник СУД 57, 1-37.

Waquet (1998): Waquet, F.. Le latin ou l'empire d'un signe: XVIe-XXe siècle, Paris: Albin Michel. 


\section{Vojin Nedeljković}

\section{THOUGHTS ON TEACHING THE CLASSICS, LATIN IN PARTICULAR, TO HIGH SCHOOLERS}

\section{Summary}

In light of the fact that in the Early Modern period the purpose of classical schooling in Europe has been defined in more than one way, the author claims that the Classics should be entrusted with the task of integrating a vast body of knowledge in the area of humanities and social sciences within the modern high-school curriculum. A possible role Latin is then discussed and conditions for its successful integration into the general curriculum are outlined.

Key words: the classical tradition, horizontal linking of high-school disciplines, the role of grammar in language teaching, working conditions in Serbia's school system, Latin, social sciences and humanities. 